\title{
8
}
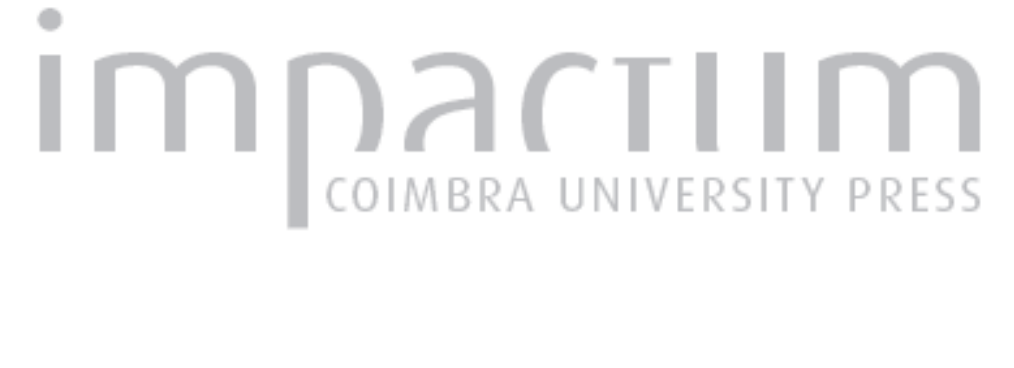

\section{Women war reporters' resistance and silence in the face of sexism and sexual violence}

\author{
Autor(es): $\quad$ Steiner, Linda
}

Publicado por: Imprensa da Universidade de Coimbra

URL persistente:

URI:http://hdl.handle.net/10316.2/42809

DOI:

DOI:https://doi.org/10.14195/2183-5462_30_1

Accessed : $\quad$ 26-Apr-2023 11:15:27

A navegação consulta e descarregamento dos títulos inseridos nas Bibliotecas Digitais UC Digitalis, UC Pombalina e UC Impactum, pressupõem a aceitação plena e sem reservas dos Termos e Condições de Uso destas Bibliotecas Digitais, disponíveis em https://digitalis.uc.pt/pt-pt/termos.

Conforme exposto nos referidos Termos e Condições de Uso, o descarregamento de títulos de acesso restrito requer uma licença válida de autorização devendo o utilizador aceder ao(s) documento(s) a partir de um endereço de IP da instituição detentora da supramencionada licença.

Ao utilizador é apenas permitido o descarregamento para uso pessoal, pelo que o emprego do(s) título(s) descarregado(s) para outro fim, designadamente comercial, carece de autorização do respetivo autor ou editor da obra.

Na medida em que todas as obras da UC Digitalis se encontram protegidas pelo Código do Direito de Autor e Direitos Conexos e demais legislação aplicável, toda a cópia, parcial ou total, deste documento, nos casos em que é legalmente admitida, deverá conter ou fazer-se acompanhar por este aviso.

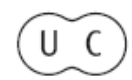


Media Jornalismo Imprensa da Universidade de Coimbra / Coimbra University Press 2 N. 30 Vol. 17, N. . 1 - 2017

\section{MULHERES E MEDIA}




\title{
WOMEN WAR REPORTERS' RESISTANCE AND SILENCE IN THE FACE OF SEXISM AND SEXUAL VIOLENCE
}

\author{
LINDA STEINER \\ University of Maryland. Philip Merrill College of Journalism. \\ College Park, Maryland 20742, EUA \\ Isteiner@umd.edu
}

Resumo

As mulheres começaram a fazer reportagens de guerra em meados do século XIX, cobrindo, entre outras guerras, as revoluções europeias e a Guerra Civil dos EUA. Com a Primeira e Segunda Guerras Mundiais e especialmente com a Guerra do Vietname, o número de mulheres repórteres de guerra aumentou ao longo do século XX. 0 seu número voltou mais recentemente a aumentar, quando muitas organizações noticiosas precisavam de jornalistas no Iraque, no Afeganistão e no Paquistão. No entanto, as reportagens de guerra permanecem amplamente consideradas como um campo dos homens. Continua a ser um campo altamente sexista. As jornalistas de guerra continuam a enfrentar condescendência, pseudo-protecionismo, desdém, comportamentos obscenos e hostilidade por parte dos seus patrões, rivais, militares e do público. São também sujeitas a violência sexual, embora sejam desencorajadas de queixar-se desses assaltos, para que possam continuar a trabaIhar. Esta investigação centra-se no sexismo e assédio sexual enfrentados por muIheres repórteres de guerra contemporâneas, com especial atenção a Lara Logan, cuja carreira demonstra muitas dessas altas tensões de género.

\section{Palavras-chave}

Mulheres repórteres de guerra; sexismo; culpadas enquanto vítimas; violência sexual

\section{Abstract}

Women began reporting on war in the mid-nineteenth century, covering, among other wars, Europeans revolutions and the US Civil War. The numbers of women reporting on war increased over the twentieth century with the First and Second World Wars and especially the Vietnam War. This increased again more recently, when many news organizations needed journalists in Iraq, Afghanistan, and Pakistan. Nonetheless, war reporting remains widely regarded as men's domain. It remains a highly sexist domain. Women war reporters continue to face condescension, pseudo-protectionism, disdain, lewdness, and hostility from their bosses, rivals, military brass, and the public. They also experience sexual violence, although they are discouraged from complaining about assaults, so that they can keep working. This research focuses on the sexism and sexual harassment facing contemporary women war reporters, with particular attention to Lara Logan, whose career demonstrates many of these highly gendered tensions.

KEYWORDS

Women war reporters; sexism; victim-blaming; sexual violence 
INTRODUCTION

In 2011 CBS chief foreign correspondent Lara Logan was raped while reporting on the resignation of Hosni Mubarak as President of Egypt. Logan, who had covered conflicts in Africa, Europe and Asia, got separated from her crew during the crush of the mobs celebrating in Cairo's Tahrir Square. She was sexually assaulted repeatedly until some women protesters closed ranks around Logan, and soldiers carried her to safety. Logan was hospitalized for four days and continued to require hospitalization at least four years later for the injuries she sustained. Once the attack became public, Logan was simultaneously demonized as an absent mother, labeled a war junkie, and mocked as a naïve, pearl necklaced ex-swimsuit model, even as others posted comments online wondering why she didn't look better. Male war reporters who are injured on assignment are lionized, but Logan was criticized: she should have known better than to gotten near volatile men. Some people criticized Logan for going to a dangerous place, while others expressed doubt that she could have been sexually attacked. Describing victim-blaming as "an old, tired game," National Public Radio deleted the nasty comments about Logan. ${ }^{1}$ Nir Rosen, a veteran Middle East war correspondent, was forced to resign a fellowship and apologize for publically joking about the attack on Logan.

Women began reporting on war in the nineteenth century, including the revolution of 1848 in Italy, the US. Civil War, and conflicts over Cuba and the Philippines. The numbers of women reporting on war increased over the twentieth century, especially during the Vietnam War. This increased again in the twenty-first century: having cut back on foreign bureaus, many news organizations needed journalists in Iraq, Iran, Afghanistan, and Pakistan. Nonetheless, war reporting is widely regarded as men's domain, quite literally requiring masculinity, given its quite literal dangers. And, relatedly, among journalism domains war reporting is among the most honored and, perhaps with sports reporting, another arena in which bodies are at risk, most sexist. So the women war reporters have faced sexism and double binds as well as hostility from the military, their own news organizations, their bosses, men and women rivals, and the public.

The contemporary context is not very different from the condescension, pseudoprotectionism, disdain, hostility, and lewdness aimed at correspondents for the Spanish American War, The First and Second World Wars, and Korea. Also a continuing issue is that women war reporters' accomplishments are ignored while their sex lives are privileged and their sexuality exploited. What is perhaps changed, problematically, is the extent to which women are exposed to sexual violence, but then discouraged from reporting such assaults and meanwhile, subjected to victim blaming and other forms of sexism. The fact that women reporters understand that they will experience these problems does not mean that such sexism and sexual assaults are not problematic, with real consequences. Therefore this chapter discusses the sexism and sexual harassment facing women reporting on recent wars. Reactions to Lara Logan demonstrate so many of the highly gendered tensions facing women war reporters, so her experiences will be highlighted, albeit not made the exclusive focus.

1 (www.npr.org/sections/thetwo-way/2011/02/16/133804167/why-have-many-comments-about-the-attack-on-lara-logan-been-removed) 
'To understand how sexism works, to ask why sexism remains stubbornly persistent in shaping worlds, determining possibilities, deciding futures, despite decades of feminist activism, is to work out and to work through the very mechanics of power.... The critique of sexism is a form of intellectual and political labour that teaches us how worlds are built; how histories become concrete' (Ahmed 2015: 5, 8). Marilyn Frye (1983) notes that refusal to recognize sexism as such itself reproduces sexism. Sexism was seemingly erased from feminist theoretical vocabularies, perhaps because complaints seemed unduly negative and/or uncreative (Ahmed, 2015). Fear of being labeled a feminist killjoy, a humorless prude, has long been a powerful disincentive to critiques from journalists no less than academics; in any case, pointing it out, much less theorizing it, is dreary and exhausting. But as feminist scholars are again insisting, theories of sexism are not only explanatory-if sexism is a means of reproduction, then institutionalized sexism helps explain what reproduction is--but also interventionist, throwing a 'wench in the works', as Sarah Franklin (2015) cleverly punned. The experience of sexual harassment and sexism is frustrating and exhausting at best; whether resisted or endured, dealing with it requires energy. As such, that diversion of energy and distraction of intelligence is essentially distorting. Producing full, rich, truthful accounts of what is going on requires a full complement of talented professionals who can put the full force of talents to the important tasks at hand.

\section{Sexual Assault and Rape}

Women reporters can be assaulted by militias, formal troops, and political sources. Ironically, an addendum to a Committee to Protect Journalists security guide suggests that guards, fixers, translators, and drivers can provide an important measure of protection against sexual assault. But guards, fixers, translators, and drivers have assaulted reporters. In 2005 more than half of the 29 women war reporters surveyed told International News Safety Institute researchers that they had been sexually harassed while on assignment. ${ }^{2}$ Many have been raped. In 2011, of about 50 journalists from around the world interviewed about their experience of sexual violence - from gang rape to aggressive groping — seven described being raped, and five others described serious sexual violation (Wolfe 2011). ${ }^{3}$ Of the few who did speak up about the experience, all but one said the response was unsupportive: they were pulled from an assignment or told to remain quiet. News executives may worry that publicizing sexual assaults will anger the foreign government or people, or cut off access to sources. No wonder that few women tell their editors or go public about the sexual assaults. Correspondents who have been sexually attacked - often in combat zones-- rarely tell anyone, whether because of cultural stigmas, doubt that authorities would act, shame or embarrassment, compulsion

2 The percentage may be low: the Institute's director said women journalists are reluctant to talk because they worry about the negative consequences if their editors feel that women require special care, attention, protection (Wolfe 2011).

3 This includes, e.g., digital penetration or sodomy with an object. A few of these victims were men, who most often were sexually assaulted while in captivity or detention. Wolfe's method was essentially a snowball survey. 
to be part of the macho club, or most likely, fear of being pulled off an assignment. This secrecy about rape means not only that they often suffer in lonely silence but also that their editors (usually men) remain unaware of the dangers and therefore do not try to increase women's security abroad or provide support.

Judith Matloff explained why she never told her editors about how a mob in India started tearing at her clothes while policemen silently watched:

I put myself out there equal to the boys. I didn't want to be seen in any way as weaker. Groping hands and lewd come-ons are stoically accepted as part of the job, especially in places where Western women are viewed as promiscuous. War zones in particular seem to invite unwanted advances, and sometimes the creeps can be the drivers, guards, and even the sources. ... But female journalists tend to grit their teeth and keep on working, unless it gets worse. (Matloff 2007).

The Swedish correspondent Jenny Nordberg, who was sexually assaulted in 2007 in Karachi, used similar language about her silence:

It's embarrassing, and you feel like an idiot saying anything, especially when you are reporting on much, much greater horrors.... did not tell the editors for fear of losing assignments.... And I just did not want them to think of me as a girl. Especially when I am trying to be equal to, and better than, the boys. I may have told a female editor though, had I had one. (in Wolfe, 2011)

Logan had been sexually assaulted in a conflict zone before Egypt (Wolfe 2011). This time she thought she would be killed. Logan told CBS' 60 Minutes: "It's not one person and it stops -- it's one person and another person and another person. ... The more I screamed, the more it turned them into a frenzy." She recalled seeing cell phone camera flashes as the frenzied crowd photographed her naked body. "I didn't even know they were beating me with flags and sticks because the sexual assault was all I could feel," she said. Tahrir Square appeared to be particularly dangerous for women. ABC'S Katie Couric was apparently "manhandled" (Trew 2011). A few months later Mona Eltahawy, an Egyptian-American journalist, described being beaten and sexually assaulted by riot police as she covered Tahrir Square protests. In 2012 Sonia Dridi, a French television journalist, was attacked by some 50 protestors before being pulled to safety by a male colleague. British journalist Natasha Smith (2012) described being sexually assaulted in the Square while filming a documentary: "All I could see was leering faces, more and more faces sneering and jeering as I was tossed around like fresh meat among starving lions." She too apparently thought she would die. On a single day in 2013 mobs assaulted 46 women protesting in Cairo; and a 22 year old Dutch intern covering the protest for an Egyptian news outlet required surgery after being gang-raped. Logan commented: "Sexual violence is a way of denying women journalists access to the story in Egypt. It's not accidental. It's by design" (Chapman \& Zahriyeh, 2012). Rape is a crime of power, not sex. Cairo shows rape committed as a war strategy, perhaps relying on group dynamics and ideologies that encourage men to act violently (Wolfe 2013). 
Kim Barker never admitted that she had been molested in Pakistan while Chicago Tribune South Asia bureau chief lest she be grounded. Because women doing international journalism have a "constant desire to prove ourselves, to show that we can play in that environment," Barker, now at ProPublica, said: "I think it's difficult for us to talk about this stuff because we don't want to look like we're weak, or whiners. The tendency of bosses is to want someone who knows what to do and doesn't need hand-holding" (Wolfe 2011). A London journalist (Trew 2011) quoted Matloff, who worked with Logan at Reuters in South Africa, saying sexual abuse "comes with the territory." "There is a lot of stigma attached to abuse, the journalists feel uncomfortable with people imagining them in their most vulnerable position". It can cost them their job. "The last thing you want is your editor not to send you out because of a fear that you could be abused. Female journalists do not want to be seen as a problem or a liability." Matloff also admired Logan for breaking taboos not merely in going public about attack, but okaying the graphic language of the CBS report: "Lara is not scared of being a lightning rod for controversy.... To get where she is, she had to prove she was one of the boys." With Logan and then when New York Times photographer Lynsey Addario wrote about being sexually assaulted when she and three other New York Times staffers were kidnapped in Libya in 2011, awareness and sensitivity to sexual violence against journalists have increased.

\section{Gossip and SeXist Language in describing Sexism}

Already in 2001 ITN's Julian Manyon jokingly attributed his access to Afghani fighters to the "physical charms" of his colleague, "the delectable Lara Logan, who exploits her God-given advantages with a skill that Mata Hari might envy" (Hodgson 2001). Logan acknowledged that Manyon was joking but replied, "It is not easy being a western woman here, one can only hope that fellow western colleagues would not fall back on hoary old chestnuts as an excuse to explain to their newsdesks why they are not getting access to the story" (Logan 2001). Over the course of the next several years, in describing Logan's speedy rise from swimsuit model to swashbuckling war correspondent, many reporters paid particular attention to Logan's war zone romances, including with rival war correspondents.

Reporting about Logan in 2011 was again replete with sexist language. Simone Wilson's (2011) LA Weekly story, featuring a photograph of the CBS "firecracker" and "sexy siren" not in the raincoat she was wearing at the time of the attack but an extremely low-cut sleeveless dress, began by saying Logan was "known for her shocking good looks and ballsy knack for pushing her way to the heart of the action." Wilson's way of expressing sympathy was saying: "We're mostly just glad the "blonde reporter" is alive today, and hopefully recovering, hopefully well on her way back to fighting the good fight for truth, journalism and girls who happen to fall on the gorgeous side of the fight for truthful journalism." No wonder Wilson needed to add "nowhere in providing links to her highly publicized past did we mean to suggest those facts had somehow led to her assault." Susan Reimer (2011, italics in original) noted: "As a result of both her beauty and her ambition, she seems to arouse a toxic combination of envy and lasciviousness in her rivals." ${ }^{4}$

4 Although this would not seem to bother Logan, another problem is that the fixation on appea- 
Logan's highly problematic 60 Minutes report accusing the US State Department and White House of covering up their negligence and incompetence regarding the attack in Benghazi revived many of the sexist critiques of Logan and her "telegenic sexual charisma, a highly useful attribute for a woman who wants to succeed in TV journalism" (Hagen 2014). Based on a story invented by a source to sell a book, Logan's report was unquestionably flawed. She had to apologize and was taken off the show. But gratuitous sexism was incorporated. The Washington Post media critic Paul Fahri (2014) presumably ignored the Tahrir Square attack in glamorizing Logan as an "almost made-for-TV" version of a foreign correspondent whose "globetrotting lifestyle and striking looks have occasionally made her tabloid fodder." Demonstrating how a reporter could criticize a cake while also eating it (using sexist language to critique sexist language), Fahri wrote:

Logan's femininity often attracts as much attention as her reporting; virtually every profile of her mentions that she was once a swimsuit model. On Halloween, people who live in Logan's neighborhood were startled to see the famous TV correspondent trick-or-treating with her children while dressed in a hot-pink bodysuit costume, set off with high heels.

In the context of painting Logan as a careerist whose risk-taking endangered colleagues and made the Benghazi error inevitable, Joe Hagan (2014) rehashed details about Logan's sex life and her access to military sources. According to Hagan, Logan was "open-eyed about the uses of sex in her profession - it was a tactic, and not to use it would be stupid, since after all, she said, men exploit their military history, brotherhood and "the macho thing." His New York Magazine profile conceded that even skeptics admired her exceptional work ethic. But he emphasized how CBS News colleagues were "appalled" by Logan's punditry. (War correspondents offer opinions all the time. Among women reporters Logan is rare for her conservative, pro-military stance, although not unique; an apt comparison is to the hawkish Marguerite Higgins, who married a military officer.) Hagan implied doubts that Logan had been sexually attacked although he offered no basis for his doubts, and several other journalists in Tahrir that day, having seen the mayhem, did not think her story was at all implausible. Suggesting that Logan might be too "toxic" to return to the show, Hagen ended by mentioning an "attractive" blonde waiting in the wings. Several journalists immediately noticed the sexism of Hagan's profile although few directly criticized it (Yaniv 2014).

Again, women also issue sexist comments about women. Spewing the bile she is famous for, the arch-conservative New York Post columnist Andrea Peyser (2001) called Christiane Amanpour a "war slut" for her post 9/11 analysis of anti-Americanism. When Amanpour, then reporting in Pakistan, complained about Peyser's remarks, Rupert Murdoch personally apologized to her. (Within the year Peyser called Amanpour a "Palestinian propagandist.") Although she noted the downsides of sexiness and the inevitable "competition in this department," and her group profile

rance can encourage women to doubt themselves, to worry that what they were wearing was responsible for being sexually assaulted —or at least to cause their editors to wonder. 
lacked the spite of Peyser, Evgenia Peretz (2002) described the "inarguably feminine" characteristics helping women war correspondents. She called Maggie O'Kane "petite and scrappy." The award-winning US-born Janine di Giovanni "has the kind of large green eyes that inspire soldiers to unload their tales of woe. ... It has also helped that all of them are easy on the eyes-a fact that none of them rushes to admit, especially Janine di Giovanni, she being perhaps the sexiest of the group."

Gossip continues about women allegedly exchanging sexual favors with military commanders or frontline troops for exclusive information or access, just as it plagued women reporting on $19^{\text {th }}$ century wars and especially throughout the $20^{\text {th }}$ century (most notably with World War II and Korea reporter Marguerite Higgins). The rumor mongering undermines women's credibility and interferes with their ability to do the job. Di Giovanni, who covered the first Palestinian intifada in the late 1980s, and became famous for covering Balkan wars in the 1990s, blamed what she called "hack-pack boys," who watched her spend hours talking with Bosnian commanders in order to gain information, and suddenly accusing her of having affairs with them:

Men are notorious gossips.... If a woman gets special access to an area or a special story, they begin sniping and saying we are using sex. Some female journalists are reluctant to talk about this kind of sexism because, in the end, we have to work with these guys. We put ourselves out on a limb. It's very tricky. (in Ricchiardi 1994)

\section{Demonizing WORKIng Mothers}

Women covering war long-term have essentially been required to remain childless. They are demonized if they don't. In 2001 the Taliban arrested Sunday Express reporter Yvonne Ridley, who had disguised herself in a burqa in order to reach Afghanistan. Ridley spent her daughter's ninth birthday in jail. Critics accused Ridley of pandering to tabloid journalism values merely to glorify her career, endangering her interpreter and driver, and especially as a single mother, immorally and recklessly leaving her child. Ridley (2001) retorted, "I thought this was an argument that was long, dead and buried and forgotten about. And here we are in the new millennium questioning my right to go out and do my job as a journalist because I'm a single mother."

The controversy was not dead, although a few war reporters claim that mothering kept them sane or made them better reporters, with sharpened insights into suffering. Hagan, for example, sudden mentioned Logan's status as a mother in calling her reckless to return to Cairo after she and her crew had already been thrown out of Egypt the week before Mubarak's resignation. Noting that men are never challenged for leaving their children at home when they go off to report on wars, war correspondent Marie Colvin condemned the "unfair" criticism of Logan. She complained:

We female correspondents are always questioned, even though quite a few male correspondents have family and children. It's infuriating. With Lara it is even worse, as she's tiny, petite and attractive with a toddler at home.... It's television so yes she's gorgeous, they don't give the job to a troll - even the men put make-up on before getting in front of the camera. Women war reporters are very responsible. They don't just leave babies with a bottle behind and get on a plane. (in Trew 2011) 
Of course, it's not a given that these women can carry pregnancies to term. Di Giovanni had three miscarriages. O'Kane once attributed her four miscarriages to having "knocked myself around a lot" while covering wars for the Guardian (Peretz 2002), although she and her journalist husband went on to have three children. Single mothers have continued to work but stop volunteering for hotspots. Fathers are not accused of damaging their children by pursuing their journalism careers. Perhaps men might similarly describe how families_or lack thereof-entered into their decision-making but they are not asked. Di Giovanni went to Libya when her son was four months old and suffered so much she vowed she would never again spend more than a week away from him. But life changes: she needed to earn a living and, she said, her work is crucial to her identity. The Dallas Morning News photojournalist Cheryl Diaz Meyer, who won the Pulitzer Prize along with her colleague for coverage of the invasion of Iraq, has described returning from Afghanistan so "angry, bitter, foul-mouthed" about the war that her husband and daughter noticed. She also described being groped and molested everyday on the front line and needing to fire her translator who didn't take well that he rejected his marriage proposal (to be a second wife). Diaz Meyer decided not to return to conflict work, given her family responsibilities. ${ }^{5}$

Among was correspondents, most men are married, while the majority of women are single (Feinstein and Sinyor 2009). The Chicago Tribune's Liz Sly warned women considering war assignments: "If you have a boyfriend, you will lose him. If you don't have one, you won't find one" (Hampton 2009, p. 148). Having covered conflict in Chechnya, the Balkans, and Albania for CNN, Siobhan Darrow (2002) quit war reporting not so much because she felt herself becoming a war junkie but because she feared a life without a family; only later did she marry (a journalist) and have children. Kristen Hampton argues that, unlike men, women "tend to view international reporting as a zero-sum career, one that can be successful only if they give up any hope of family or personal life" (2009, p. 143). Hampton quit the Chicago Tribune after becoming romantically involved with an Army officer she met in Iraq.

Meanwhile, women often feel selfish and guilty about the worry they inflict on loved ones. Some women took on war assignments only after getting divorced. Elizabeth Neuffer, who covered conflicts in Bosnia, Albania, Kosovo, Rwanda, and Afghanistan for the Boston Globe, once observed that "being a war correspondent is an act of violence against the people you love the most because they end up having to stay behind worrying about you" (Lee 2002). Having been menaced by armed rebels, subjected to death threats, abducted by soldiers, and threatened with rape, Neuffer was killed in a car accident in Iraq in 2003. Christiane Amanpour, for years CNN's chief international correspondent, reported on Rwanda, Bosnia, two Gulf Wars, and Afghanistan. Amanpour described the challenge of always living in "fear of being shot... of being kidnapped, of being raped by some lunatic who hates your stories or blames you for bringing NATO bombs down around them. We manage the fear, but the strain takes its toll" (Amanpour 2000).

5 Presentation, University of Maryland College of Journalism, Sept 28, 2015. 
Women war correspondents face a highly gendered form of victim blaming. Amanda Lindhout, who went to Somalia because she "really, truly cared about the human suffering in those places" (Wolfe 2013), was kidnapped in 2008 along with Nigel Brennan, her photographer. The teenage captors freed their Somali translator and driver after 150 days. After 460 days, she and Brennan were ransomed for over $\$ 600,000$. Lindhout, a Canadian, had previously worked for an Iranian new startup but was a wholly unprepared novice--although formal training is hardly a prerequisite. Brennan was beaten. The kidnappers raped Lindhout and called her dirty and evil. After her release, readers attacked Lindhout's "stupid decision" with crudely misogynist language. Two woman reporters asked her whether she thought she was raped because she's "pretty" — whether she "tempted" the kidnappers. After emphasizing Lindhout's photogenic looks, the Guardian and Mail conservative columnist Margaret Wente (2013) conceded that Lindhout had endured dreadful and undeserved gang rape, starvation and disease. Yet, she declared: "[M]y sympathy is tempered by the fact that narcissistic, recklessly naive people like Ms. Lindhout are often their own worst enemies. They bring trouble not only on themselves, but on their families, their helpers and fixers and the governments that get involved in rescuing them."

\section{THE INTERSECTION OF LOOKISM AND ECONOMICS}

Among the several facets of sexism that has persisted over the last half-century-that is, since the innovation of television reporting-- is the requirement that women broadcast and cable reporters and anchors be attractive. Women describe needing to carry make-up into combat zones so that they can look good. A number of these problems, including how "lookism" constitutes a double bind, came into focus with Logan, whose beauty was unfailingly highlighted but also used against her. In 2002 The Sun (Lazzeri, 2002) accused "TV beauty Lara Logan" for "flashing her cleavage" at Royal Marines in Afghanistan. A source said a series of "sexy manoeuvres" irritated officers and troops alike: "Lara is a gorgeous-looking woman, there is no denying that. But a military base in a war zone is not a place for being flirtatious." Another story was headlined "Put Those Bazookas Away, Lara." And her looks might even be insufficient with broadcast executives. Lara Logan complained when one of her Iraq reports was not aired but merely posted on the Web. The executive director of the news show regarded some of the report's images as "a bit strong" (Ricchiardi 2007).

Some of the shifts in war reporting, including the increased use of women, reflects economics. News executives have long sought ways to boost audience numbers, and one way is by hiring attractive women. In 2001, calling herself an "ageing old trout," veteran war correspondent Kate Adie criticized BBC management for softening news by hiring women without journalism experience but having "cute faces, cute bottoms and nothing else in between" (Cohen 2001). Adie, who was shot at in Libya and again injured in Bosnia, was undoubtedly overly cynical. Presumably women are not assigned to cover combat merely to spice up the drama. Several reporters noted that as a younger woman Adie was not above wearing mini-skirts and tight sweaters when on-air. Meanwhile, the BBC's Jacky Rowland, dubbed one of the new "Kate Adies," openly resented Adie's claim that television execu- 
tives were more concerned about the "shape of your leg" than professional ability: "To see that the person who inspired me as a teenager is making bitchy comments about the young women who are following in her footsteps, I just don't think that does justice to a proud tradition" (Peretz 2002). That said, market-driven television executives apparently believe that pretty faces leaven the sight of body bags and several of them admit being an attractive female helped in getting particular stories and helped their careers.

The question becomes however, not merely the sexism of describing women in terms of their beauty and making sure they look good (men wear make-up for the camera, too, but the standards are far less exacting) but exploiting women in the increasingly risky post $9 / 11$ conflicts. In twentieth century wars, reporters, at least those from the US, wore US military uniforms and travelled with troops. In contrast, now reporters travel alone, often with rebels. A second change regards the longstanding taboo on intentionally harming women journalists. One former war reporter says attacking Western women journalists represents a "war zone trifecta" (Hampton 2009, p.145). In 2001, Taliban leaders promised to reward the murder of Western journalists; two women were among the eight killed in the next seventeen days.

All contemporary reporters covering conflicts are increasingly vulnerable. Twentieth century wars were primarily waged by national armies with well-defined battle zones; even during Vietnam, at least US reporters often wore US military-issued uniforms and traveled with US troops. In contrast, now many reporters go solo on the rebel side. Moreover, using women as stringers and freelancers points to a profit-driven shift to cheaper workers with increasingly problematic implications: Freelancers, who are typically young, inexperienced, and disproportionately idealistic, take risks that reflect not careerism, but idealism. And no news organization is responsible for paying ransom if they are kidnapped. They lack medical benefits or support if injured. They lack the training, services, and back up support of an employing news organization. They cannot afford the best fixers. And women historically have been disproportionate among free-lancers, including with respect to conflict reporting. ${ }^{6}$

A case in point is the first Western journalist to die while covering conflict in the Central African Republic, a French photojournalist. Camille Lepage, 26, had gone to South Sudan in 2012. Her work was used by French, British, and German newspapers, The New York Times, The Washington Post, and Wall Street Journal, Al Jazeera and especially BBC, and several major several non-governmental organizations. Lepage told an interviewer (Jones 2013) she was shocked by the little coverage devoted to South Sudan and CAR, and annoyed by the pessimism about it:

"I had to go and report from there... I became very keen on the duty of a journalist to tell stories and make them accessible to a broad audience. I also realized what the media agenda was, and how so many serious stories were missing from the headlines simply because they don't fit within that agenda, or the advertising company's interests. I can't accept that people's tragedies are silenced simply be-

6 Freelance journalism is romanticized for its supposed autonomy and freedom from bureaucracy and office politics; but is marked by declining incomes, layoffs, and competition, partly, McKercher (2009) says, because freelance journalism is "women's work." 
cause no one can make money out of them. I decided to do it myself, and bring some light to them no matter what."

\section{POST-TRAumatic STRESS DISORDER}

The dangers, pressures and strains of modern war reporting affect both men and women: war reporters apparently develop Post-Traumatic Stress Disorder (PTSD) at a rate five times higher than the general population. A study of frontline journalists who worked in conflict zones, of whom $25 \%$ were women, found that women drink just as much, if not more, than the men-although men are generally much more likely than women to drink to excess (Feinstein and Sinyor 2009). Journalists who cover death and destruction think of themselves as unusually tough, impervious or immune to the reverberating impact of the human suffering they witness. Until recently, journalists felt that if they publicly acknowledged that reporting experiences might affect them long-term, the journalist would be thought of as weak and less capable.

Certainly women are not more likely to get PTSD. Janine di Giovanni (2011) described moving to Paris so she could deliver a child after years of conflict reporting and depression, death, suicide of friends, addiction, alcohol use, and several times when either she or her husband, a French photographer she met in Sarajevo, nearly died. Her baby was fine. But di Giovanni suddenly developed fears and obsessions with the birth of her son, although she recovered. Two years later, her husband developed debilitating PTSD, leading to the end of the marriage. Marie Colvin married a battle-hardened Sunday Telegraph reporter, then "unaware that falling in love in a war zone often means acquiring an ex-husband" (Peretz 2002). The marriage lasted two years. Soon after, covering violence in the West Bank, Colvin met, married, and soon split up from a reporter for El Pais, who later developed PTSD and committed suicide.

But if journalism's macho code discourages men from seeking treatment for PTSD, women are probably equally unlikely to admit weaknesses and thus equally unwilling, or more so, to get treatment. In any case, the silence about it is a major problem. Freelance journalist Nadine Marroushi (2014) said her own debilitating bout of PTSD began when she went to Sinai: "I just wanted to do my job: bear witness and report." But she had no hostile environment training, and her problems were compounded by exhausting and daily street sexual harassment. She suffered panic attacks, depression, and suicidal thoughts. She was particularly shaken when, reporting from Tahrir Square in 2014, a citizens' mob attacked her, believing, incorrectly, that she worked for Al-Jazeera. And finding little discussion about journalists' experiences of PTSD, she said, "It was as though it was a taboo subject, and I felt embarrassed that I was experiencing this."

\section{Conclusion}

Regardless of journalistic beat, women and men tend to have similar epistemologies and to evaluate journalism, journalism ethics, and journalistic identities in similar ways. This may be attributed to socialization into a shared, dominant ideology and journalistic culture. Women reporters do not share some gender-specific style of reporting or journalistic philosophy. Their motives for war reporting differ. Many feel 'called' to bear witness to the injustice, tragedy and horror of war, and 
even bring about action and policy change. O'Kane was a "one-woman war-crime tribunal," taking on the responsibility of hunting down murderers; to O'Kane, "the truth isn't objective" (Peretz 2002). Fifteen months before she was killed in Syria, at a service honoring journalists killed in the line of duty, Marie Colvin (2010) said journalists' mission is to report the "horrors of war with accuracy and without prejudice. We always have to ask ourselves whether the level of risk is worth the story." But in East Timor in 1999, after the U.N. staff and the journalists decided to evacuate in the face of machete-wielding militiamen, Colvin stayed behind to act as a human shield for 1,500 Timorese women and children. Colvin's reports apparently led the U.N. reversed its decision and got the civilians to safety. But some simply came to this work as a career involving balance and impartiality, while others sought adventure. What they may share, however, is the pressure to prove themselves, and thus to take risks to advance their careers.

In some sense, this supports contemporary feminists, such as Judith Butler, who treat the social construction of gender not as a matter of 'natural' behavior but rather involving repeated and rewarded performances of gendered ideas. These performances can and do change over time as well as vary across culture. Notions about gender roles and about masculinity and femininity have changed greatly, albeit unevenly by news organization and especially by country. Indeed, while this account is regrettably US-centric, increasingly women from around the world are reporting on war-- are being killed, imprisoned, banned, or threatened for doing so. Meanwhile, sexism, if not misogyny, and sexual abuse of women reporters continue, literally and overtly, and also globally.

So, what enables some women to battle through the Catch-22s, double standards, and anti-women, or at least ignore it? In order to avoid unnecessary and gratuitous psychologizing, no attempt has been made to explain why some women actively resist sexism or sexual harassment, while others silently put up with it and still others quit either as a result of their experiences or others' refusal to stop it. But certainly it is worth noting that women have dealt with sexism almost always as individuals and almost never collectively, and that the most common way of coping with it seems to be to endure in silence, if not to ignore it. Furthermore, analyzing how women students are marginalized when experiencing and discussing sexual harassment, Leila Whitley and Tiffany Page (2015) draw on Miranda Fricker's (2007) observation that women's testimony can be relegated and dismissed through "epistemic marginalization" or "epistemic injustice," because of the prejudices of an individual hearer or structural identity. Their point is that when women insist that sexual harassment exists-- by complaining or refusing to go along with unwelcome advances-- the problem can be reconstructed as one of complaining women; the problem sticks not the harasser but to those who expose the problem and complain about it, relocating the problem in ways that cause it to disappear.

This would easily apply to the newsroom, with its insistence that journalists transcend their bodies in the interests of objectivity, and to the decidedly hyper-masculinized culture of conflict zones, in which women attempt to outmacho the men. Women

7 Presumably in the US, women's increasing visibility and authority as soldiers and military officers, public information officers and government leaders helped women war reporters. 
are not going to complain about sexism for a wide variety of compounding reasons: Women are trained and socialized to be tough and professional, and to ignore their bodies as journalists; then in a war zone, they frightened that their bodies will give them away. Their self-regard and status as professionals, as well as their need to get along with male colleagues or rivals, urges concealment of irritation. Their interest in getting access to and information from ground troops and military brass from all sides suggests the value of deploying femininity. In this context, and given the stigma of being called a killjoy, and the danger of having complaints attached to the complainers, they are not going to report sexism and sexual harassment.

One factor seems quite clear: Solidarity as women is not a prominent resource for women in journalism, including war reporters. Historically and in the present, most women reporters have been hostile to feminism, credit their success to their individual hard work and express little or no interest in sisterhood. According to Peretz (2002), "The Girls at the Front" think an article about female war correspondents is "pretty lame," because they are reporters, not women reporters, as rugged as any man. Occasions of solidarity are rare: "They have elbowed each other out of the way to get the story, and gossiped behind one another's backs." This seems to have continued to be the case; these women assume that feminism is unnecessary or even unhelpful in addressing the sexism they will inevitable face.

Meanwhile, the increased use of women foreign correspondents as stringers and freelancers perhaps simply shows a profit-driven shift to cheaper workers and away from expensive ones; with foreign bureaus and even entire news organizations closing, freelancing is more permanent. ${ }^{8}$ But it is a major problem, especially for women, intent on proving themselves even while they have a harder time getting fulltime work. Storyhunter not only provides publishing tools, editorial support, and distribution opportunities for freelancers but also claims to provide safety training and insurance coverage. But this is a Band-Aid — a stop-gap solution. ${ }^{9}$ If they cannot afford to do this individually, news organizations should form consortiums to manage the freelance work, provide support, and assist reporters who come in harm's way.

Volunteers for conflict reporting are likely to continue coming from the ranks of ambitious, young, single--and female--reporters. But organizations (conventional news outlets, foundations, platforms like Storyhunter and ProPublica) need to be clear and explicit about the risks and not pressure reporters to undertake unnecessary risks. News organizations should not sexualize women reporters by coercing them to look sexy, even when reporting from combat zones, which arguably undermines their professionalism. News organizations need to openly discuss sexual assault not merely to minimize risk and abuse but also so that reporters know to recognize-in themselves or others - the signs of PTSD, to ensure that reporters feel free to say when they have been sexually molested or assaulted, or if they are suffering PTSD. A private security company had included rape and assault in its safety training but dropped it because men were uncomfortable with it (Dart Center 2005). Hostile Environment courses should acknowledge gender-sensitive issues, and women should offer the training. Reporters need to know about resources and news organizations

8 In 2015 the McClatchy chain discontinued its foreign bureaus.

9 Moreover, all of Storyhunter's top executives are men. (https://storyhunter.tv/) 
should pay for therapy. Wolfe (2011) found that only NBC was designing a specific curriculum to prepare journalists to prevent and deal with sexual assault and how to identify PTSD. That NBC program also included medical advice; the morning-after pill and an HIV blocker will be prescribed upon request. An NBC representative said that creating a course was "very challenging" because there is no model from which to draw, but that reporters would be reassured that disclosing a sexual assault will not result in being pulled off a story. News organizations need to step up to the plate. As with the issue of sexism, the solution - vague as it is - can only be institutional change, a transformation of the culture.

\section{References}

Ahmed, Sara (2015). "Sexism - A Problem with a Name." New Formations: A Journal of Culture/Theory/Politics, 86: 5-13.

Amanpour, Christiane (2000). "Speech to the Radio and Television News Directors Association." http://gos.sbc.edu/a/amanpour.html

Chapman, Ben \& Zahriyeh, Ehab (2012, October 21). "French TV journalist Sonia Dridi attacked by out-of-control protesters in Cairo in same square where CBS' Lara Logan was sexually assaulted." Daily News http://www.nydailynews.com/news/world/french-tv-journalist-sonia-dridi-attacked-out-of-control-protesters-cairo-article-1.1188430

Cohen, Nadia (2001, October 24). "Adie slams BBC's 'cute faces policy," London Evening Standard, http://www.standard.co.uk/news/adie-slams-bbcs-cute-faces-policy-6336230.html

Colvin, Marie (2010) 'Our mission is to report these horrors of war with accuracy and without prejudice.' Available at http://www.theguardian.com/commentisfree/2012/feb/22/marie-colvin-our-mission-is-to-speak-truth?intcmp=239

Darrow, Siobhan (2002). Flirting With Danger: Confessions of a Reluctant War Reporter. Anchor.

Dart Center (2005) Women Reporting War, Feb. 5. http://dartcenter.org/content/women-reporting-war\#.Vil_iSuhRqs

di Giovanni, Janine (2011). Ghosts by Daylight: A Memoir of War and Love. Bloomsbury

Farhi, Paul (2013 November 11). CBS News and reporter Lara Logan face brutal criticism on flawed Benghazi report. https://www.washingtonpost.com/lifestyle/style/cbs-news-and-reporter-lara-logan-face-brutal-criticism-on-flawed-benghazi-report/2013/11/11/ b2f55d8c-4b1f-11e3-ac54-aa84301ced81_story.html

Feinstein, Anthony \& Sinyor, Mark (2009) "Women War Correspondents: Different in So Many Ways." Neiman Reports, Winter, http://www.nieman.harvard.edu/reports/article/101967/Women-War-Correspondents-They-Are-Different-in-So-Many-Ways.aspx

Franklin, Sarah (2015). "Sexism as a Means of Reproduction: Some Reflections on the Politics of Academic Practice." New Formations: A Journal of Culture/Theory/Politics, 86: 14-33.

Fricker, Miranda (2007). Epistemic Injustice: Power \& the Ethics of Knowing, Oxford: Oxford University Press.

Frye, Marilyn (1983). The Politics of Reality: Essays in Feminist Theory. New York: Crossing Press. Hagan, Joe (2014, May 4). "Benghazi and the Bombshell: Is Lara Logan too toxic to return to $60 \mathrm{Mi}-$ nutes?" New York Magazine. http://nymag.com/news/features/lara-logan-cbs-news-2014-5/ 
Hampton, Kirsten Scharnberg (2009). "Covering War Through a Woman's Eyes." in Nicholson, June 0., Creedon, Pamela J., Lloyd, Wanda S. \& Johnson, Pamela J. (eds) The Edge of Change: Women in the Twenty-first Century Press (pp. 143-154). Urbana: University of Illinois Press.

Hodgson, Jessica (2001, November 5). “GMTV's Logan counters 'Mata Hari' jibe." MediaGuardian, http://www.guardian.co.uk/media/2001/nov/05/terrorismandthemedia. broadcasting

Jones, Gregory Eddi (2013, October 22). "Hidden World of South Sudan: An Interview with Photojournalist Camille Lepage." PetaPixel. http://petapixel.com/2013/10/22/hidden-world-south-sudan-interview-photojournalist-camille-lepage/

Lazzeri, Antonella (2002, May 22). "Marines rap busty TV girl." The Sun. http://www.thesun. co.uk/sol/homepage/news/article149727.ece

Lee, Carol (2002, April 17). "Foreign Correspondent Willing to Return to Danger Zone." Women's eNews, http://www.womensenews.org/story/journalist-the-month/020417/ foreign-correspondent-willing-return-danger-zone

Logan, Lara (2001, November 5). "Life at the front." MediaGuardian,http://www.guardian. co.uk/media/2001/nov/05/terrorismandthemedia.broadcasting

Marroushi, Nadine (2014, Sept. 4). "Breaking the Taboo: 'I reported from conflict zones and got post-traumatic stress disorder."' The Telegraph. www.telegraph.co.uk/women/womens-life/11074792/Isil-beheading-of-Steven-Sotloff-I-reported-from-conflict-zones-and-got-post-traumatic-stress-disorder.html

Matloff, Judith (2007, May/June). "Unspoken Foreign Correspondents and Sexual Abuse." Columbia Journalism Review, http://www.cjr.org/on_the_job/unspoken.php

McKercher, Catherine (2009). "Writing on the Margins: Precarity and the Freelance Journalist." Feminist Media Studies, 9(3): 370-374.

0'Kane, Maggie (2005). "Reporting on Women during Armed Conflict: A War Journalist's Perspective." In Helen Durham and Tracey Gurd (eds.), Listening to the Silence: Women and War (pp. 89-93). Netherlands: Koninklijke Brill BV.

Peretz, Evgenia (2002, June). "The Girls at the Front." Vanity Fair, http://www.vanityfair. com/politics/features/2002/06/female-war-correspondents-200206

Peyser, Andrea (2001, September 21). "America-Bashing U.N. Should Get Lost." http://nypost.com/2001/09/21/america-bashing-u-n-should-get-lost/

Reimer, Susan (2011, February 21). For female war reporters, a fight on multiple fronts. Baltimore Sun

Ricchiardi, Sherry (1994, March). Women on War. American Journalism Review http://ajrarchive.org/Article.asp?id=1513

Ricchiardi Sherry (2007, April/May). "Obstructed View." American Journalism Review, http:// ajrarchive.org/archive.asp?issue $=84$

Ridley, Yvonne (2001). Interviewed by Michael Buerk, 30 October, for 'The Choice', BBC Radio 4. Shadid, Anthony, Addario, Lyndsey, Farrell, Stephen \& Hicks, Tyler (2011, March 22). "4 Times Journalists Held Captive in Libya Faced Days of Brutality." New York Times, p. A1. Skiba, Katherine M. (2005) Sister in the Band of Brothers. Lawrence: University Press of Kansas. 
Smith, Natasha (2012, June 26). "Please God. Please make it stop." https://natashajsmith. wordpress.com/2012/06/26/please-god-please-make-it-stop/

Spinner, Jackie (2006). Tell Them I Didn't Cry: A Young Journalist's Story of Joy, Loss, and Survival in Iraq. New York: Scribner.

Trew, Bel (2011, February 17). "Lara is never scared of being a lightning rod for controversy." The Evening Standard. http://www.standard.co.uk/lifestyle/lara-logan-is-never-scared-of-being-a-lightning-rod-for-controversy-6568307.html

Wente, Margaret (2013, Sep. 10). "Amanda Lindhout, innocent abroad - and recklessly naïve." The Globe and Mail. http://www.theglobeandmail.com/commentary/amanda-lindhout-innocent-abroad-and-recklessly-naive/article14213143/?cmpid=rss1

Whitley, Leila \& Tiffany Page (2015). "Sexism at the Centre: Locating the Problem of Sexual Harassment', New Formations: A Journal of Culture/Theory/Politics, 86: 34-53

Wilson, Simone (2011, February 16). "Lara Logan, CBS Reporter and Warzone 'It Girl' Raped Repeatedly Amid Egypt Celebration." LA Weekly. http://www.laweekly.com/ news/lara-logan-cbs-reporter-and-warzone-it-girl-raped-repeatedly-amid-egypt-celebration-2395540

Wolfe, Lauren (2013, September 24). "Abused for Surviving: What Amanda Lindhout Faces After Captivity." The Nation, https://www.thenation.com/article/abused-surviving-what-amanda-lindhout-faces-after-captivity/

Wolfe, Lauren (2011, June 7). "The Silencing Crime: Sexual Violence and Journalists. "Committee to Protect Journalists. https://www.cpj.org/reports/2011/06/

Yaniv, Oren (2014, May 6). "Story on CBS' Lara Logan in New York magazine slammed as sexist." New York Daily News, http://www.nydailynews.com/news/national/lara-logan-story-new-york-magazine-slammed-sexist-article-1.1780983

Linda Steiner - é professora no Philip Merrill College of Journalism, na Universidade de Maryland, nos Estados Unidos. Linda Steiner tem estudado como e quando o género é importante nas notícias e redações e como as feministas usam os media, tendo inúmeras publicações neste domínio. É Editora-Chefe da Revista Journalism \& Communication Monographs e participa do concelho editorial da revista Critical Studies in Media Communication.

Article by invitation / Artigo por convite 